\title{
New nephropid lobster (Decapoda: Astacidea) from the late Campanian of California; extending the range of Pacific coastal fossil lobster occurrences
}

\section{Nueva langosta nefrópida (Decapoda: Astacidea) del Campaniano tardío de California; ampliando el alcance del registro de langostas fósiles en la costa del Pacífico}

LSID urn:lsid:zoobank.org:pub:219D9751-2793-4430-9AA6-C9FC5E2053C0

Rodney M. Feldmann ${ }^{1, *}$, Carrie E. Schweitzer ${ }^{2}$

${ }^{1}$ Department of Geology, Kent State University, Kent, OH 44242, USA.

${ }^{2}$ Department of Geology, Kent State University Stark Campus, 6000 Frank Ave. NW, North Canton, OH 44720, USA.

* Corresponding author: (R. Feldmann) rfeldman@kent.edu

\section{How to cite this article:}

Feldmann, R.M., Schweitzer, C. E., 2021, New nephropid lobster (Decapoda: Astacidea) from the late Campanian of California; extending the range of Pacific coastal fossil lobster occurrences: Boletín de la Sociedad Geológica Mexicana, 73 (3), A241220. http://dx.doi. org/10.18268/BSGM2021v73n3a241220
Manuscript received: August 2, 2020

Corrected manuscript received: August 26, 2020

Manuscript accepted: August 30, 2020

Peer Reviewing under the responsibility of Universidad Nacional Autónoma de México.

This is an open access article under the CC BY-NC-SA license(https://creativecommons.org/licenses/by-nc-sa/4.0/)

\begin{abstract}
Two well preserved specimens of nephropid lobster from the Late Cretaceous (late Campanian) Point Loma Formation in San Diego County, California, form the basis of description of a new species of Hoploparia. The occurrence represents the southernmost fossil record of macrurans along the Pacific coast of North America and it is only the third fossil lobster from California.
\end{abstract}

Keywords: Cretaceous, Nephropoidea, Nephropidae, Hoploparia.

\section{RESUMEN}

Dos especimenes bien conservados de langosta de nefrópidos, de la Formación Point Loma del Cretácico Tardío (Campaniano tardío) en el condado de San Diego, California, forman la base para la descripción de una nueva especie de Hoploparia. Este acontecimiento representa el registro fósil de macruras en el extremo sur a lo largo de la costa del Pacífico de América del Norte, y se trata de la tercera langosta fósil de California.

Palabras clave: Cretácico, Nephropoidea, Nephropidae, Hoploparia. 


\section{Introduction}

The fossil decapod fauna of the west coast of North America is dominated by anomurans and brachyurans. Macrurans, the lobsters and their relatives (Table 1), are far less common and less diverse. The preponderance of their occurrences is in the north, in Washington and Alaska, USA, and in British Columbia, Canada. Previously, a single species, Hoploparia shastensis (Rathbun, 1929) was recorded in California. The sole specimen of that species was collected in Shasta County near the Oregon border. Enoploclytia trisulcata (Schweitzer and Feldmann, 2001) was reported from the Cenomanian Antelope Shale in Colusa County, also in northern California. Thus, the discovery of specimens of nephropid lobsters in San Diego County, the southernmost county in the state, significantly extends the southern range of Pacific coast lobsters and adds a new species of Hoploparia to the North American decapod fossil fauna.

Prior to this work, two brachyurans were recorded from the Point Loma Formation near Carlsbad, San Diego County (Bishop, 1988). Xandarocarcinus sternbergi (Rathbun, 1926) and Icriocarcinus xestos (Bishop, 1988), were collected from the same locality as the new species of lobster described herein. The specimens documenting these species were collected from an $800 \mathrm{ft}$. (244 m) road cut during excavation of the extension of College Boulevard in 1986 and 1987. The excavation exposed $90 \mathrm{ft}$. (27.5 m) of Cretaceous mudstone and shale containing abundant molluscs, the decapods, other invertebrates, vertebrates, and plants (Deméré, 1987), donated by the Koll Construction Company.

The purpose of the present work is to describe a new species of nephropid decapod crustacean from the Late Cretaceous of North America and to add to the vagrant benthic predator/scavenger fauna within the Point Loma Formation.

\section{Methods}

Specimens were prepared by the staff of the San Diego Natural History Museum, Department of Paleontology. Photographic illustrations were prepared using a Nikon D3100 camera with an AF-S micro Nikkor $60 \mathrm{~mm}$ lens. Contrast and brightness were optimized in Adobe Photoshop CC2018. Abbreviations for morphological features of the cephalothorax follow Holthuis (1974). SDSNH denotes the San Diego Natural History Museum, San Diego, California, USA.

\section{Systematic paleontology}

Order Decapoda Latreille, 1802

Infraorder Astacidea Latreille, 1802

Superfamily Nephropoidea Dana, 1852

Family Nephropidae Dana, 1852

Hoploparia M'Coy, 1849

Type species. Astacus longimanus Sowerby, 1826, by subsequent designation of Rathbun (1926).

Included species. See Schweitzer et al., 2010, plus $H$. bretoni new species; H. nasilowensis Fraaije et al., 2018.

Discussion. Tshudy et al. (2018) summarized work done on Hoploparia and other nephropid genera. They suggested that although the range of variation among species currently assigned to $H_{o p}$ loparia is wide, there is no obvious way to subdivide the genus. Thus, they, and we, maintain the genus as currently construed.

\section{Hoploparia bretoni $\mathrm{n}$. sp. \\ Figures 1, 2}

LSID urn:lsid:zoobank.org:pub:219D9751-27934430-9AA6-C9FC5E2053C0

Etymology. The trivial name honors the late Gérard Breton, who contributed much to the paleontology of France, and to that of decapod crustaceans.

Types. Holotype, SDSNH 34151, and paratype, SDSNH 34152, deposited in the San Diego Natural History Museum, San Diego, California, USA.

Locality and stratigraphic position. The specimens were collected at SDSNH locality 3405, latitude 33.139519, longitude -117.283928, Carlsbad, San Diego County, California, USGS 1:24000 San Luis Rey, California topographic 
Table 1. North American Pacific coast lobsters and their occurrences. E, e, early; L, I, late; M, m, middle.

\begin{tabular}{|c|c|c|c|c|c|}
\hline Generic placement & Species & Authority & Age & Formation & Location \\
\hline \multicolumn{6}{|l|}{$\begin{array}{l}\text { Infraorder Polychelida } \\
\text { Scholtz and Richter, } 1995\end{array}$} \\
\hline \multicolumn{6}{|l|}{$\begin{array}{c}\text { Family Eryonidae de } \\
\text { Haan, } 1841\end{array}$} \\
\hline Wrangelleryon & & $\begin{array}{l}\text { Feldmann, Schweitzer } \\
\& \text { Haggart, } 2013\end{array}$ & & & \\
\hline Wrangelleryon & perates & $\begin{array}{l}\text { Feldmann, Schweitzer } \\
\& \text { Haggart, } 2013\end{array}$ & Early Jurassic, Hettangian & $\begin{array}{l}\text { Sandilands } \\
\text { Formation }\end{array}$ & $\begin{array}{l}\text { British Columbia, } \\
\text { Canada }\end{array}$ \\
\hline \multicolumn{6}{|c|}{$\begin{array}{l}\text { Palaeopentachelidae Ahyong, } \\
2009\end{array}$} \\
\hline \multicolumn{6}{|l|}{ Palaeopentacheles } \\
\hline Palaeopentacheles? & starri & $\begin{array}{l}\text { Schweitzer and } \\
\text { Feldmann, } 2001 \\
\end{array}$ & Oligocene & Makah Formation & Washington, USA \\
\hline \multicolumn{6}{|l|}{$\begin{array}{l}\text { Infraorder Achelata Scholtz \& } \\
\text { Richter, } 1995\end{array}$} \\
\hline \multicolumn{6}{|l|}{ Palinuridae Latreille, 1802} \\
\hline Linuparus & & White, 1847 & & & \\
\hline Linuparus & canadensis & Whiteaves, 1885 & e. Campanian & $\begin{array}{l}\text { Nanaimo Group } \\
\text { Pender Formation }\end{array}$ & $\begin{array}{l}\text { Vancouver \& Hornby } \\
\text { islands, BC, Canada }\end{array}$ \\
\hline Linuparus & vancouverensis & Whiteaves, 1895 & e. Campanian & $\begin{array}{l}\text { Nanaimo Group, } \\
\text { Pender Formation }\end{array}$ & $\begin{array}{l}\text { Vancouver \& Hornby } \\
\text { islands, BC, Canada }\end{array}$ \\
\hline \multicolumn{6}{|l|}{ Scyllaridae Latreille, 1825} \\
\hline Scyllarella & & Rathbun, 1935 & & & \\
\hline Scyllarella & manleyi & $\begin{array}{l}\text { Feldmann \& } \\
\text { Schweitzer, } 2017\end{array}$ & Eocene & $\begin{array}{l}\text { Lookingglass } \\
\text { Formation }\end{array}$ & Oregon \\
\hline \multicolumn{6}{|c|}{$\begin{array}{l}\text { Infraorder Glypheidea } \\
\text { Winckler, } 1881\end{array}$} \\
\hline \multicolumn{6}{|c|}{ Erymidae Van Straelen, 1925} \\
\hline Enoploclytia & & M'Coy, 1849 & & & \\
\hline Enoploclytia & minor & Woodward, 1900 & $\begin{array}{l}\text { L. Cretaceous (1. } \\
\text { Campanian - e. } \\
\text { Maastrichtian) }\end{array}$ & Spray Formation? & $\begin{array}{l}\text { Hornby Island, BC, } \\
\text { Canada }\end{array}$ \\
\hline Enoploclytia & trisulcata & $\begin{array}{l}\text { (Schweitzer \& } \\
\text { Feldmann, 2001) } \\
\end{array}$ & $\begin{array}{l}\text { L. Cretaceous } \\
\text { (Cenomanian) }\end{array}$ & Antelope Shale & California, USA \\
\hline Pustulina & & Quenstedt, 1857 & & & \\
\hline Pustulina & dawsoni & (Woodward, 1900) & $\begin{array}{l}\text { L. Cretaceous (1. } \\
\text { Campanian - e. } \\
\text { Maastrichtian) }\end{array}$ & Spray Formation? & $\begin{array}{l}\text { Hornby Island, BC, } \\
\text { Canada }\end{array}$ \\
\hline Stenodactylina & & Beurlen, 1928 & & & \\
\hline Stenodactylina & walkerae & $\begin{array}{l}\text { (Feldmann \& Haggart, } \\
2008 \text { ) }\end{array}$ & $\begin{array}{l}\text { M. Jurassic (e. Bajocian - e. } \\
\text { Callovian) }\end{array}$ & $\begin{array}{l}\text { Smithers } \\
\text { Formation }\end{array}$ & $\begin{array}{l}\text { British Columbia, } \\
\text { Canada }\end{array}$ \\
\hline Stenodactylina & beardi & $\begin{array}{l}\text { Feldmann, Schweitzer } \\
\text { \& Haggart, } 2020\end{array}$ & $\begin{array}{l}\text { L. Cretaceous (1. Santonian } \\
\text {-e. Campanian) }\end{array}$ & Haslam Formation & $\begin{array}{l}\text { Vancouver Island, BC, } \\
\text { Canada }\end{array}$ \\
\hline \multicolumn{6}{|l|}{$\begin{array}{l}\text { Chimaerastacidae Amati et } \\
\text { al., } 2004\end{array}$} \\
\hline Chimaerastacus & & $\begin{array}{l}\text { Amati, Feldmann \& } \\
\text { Zonneveld, } 2004\end{array}$ & & & \\
\hline Chimaerastacus & pacifluvialis & $\begin{array}{l}\text { Amati, Feldmann \& } \\
\text { Zonneveld, } 2004\end{array}$ & $\begin{array}{l}\text { Middle Triassic (Ladinian- } \\
\text { Carnian) }\end{array}$ & & $\begin{array}{l}\text { British Columbia, } \\
\text { Canada }\end{array}$ \\
\hline Glypheidae & & Winckler, 1881 & & & \\
\hline Glyphea & & Von Meyer, 1835 & & & \\
\hline Glyphea & sp. & Whiteaves, 1903 & Cretaceous & Nanaimo & $\begin{array}{l}\text { Vancouver Island, BC, } \\
\text { Canada }\end{array}$ \\
\hline Trachysoma & & Bell, 1858 & & & \\
\hline Trachysoma & micheleae & $\begin{array}{l}\text { (Schweitzer \& } \\
\text { Feldmann, 2001) }\end{array}$ & Eocene (Lutetian) & Aldwell Formation & Washington, USA \\
\hline \multicolumn{6}{|l|}{$\begin{array}{l}\text { Mrachysoma } \\
1925\end{array}$} \\
\hline Meyeria & & M'Coy, 1849 & & & \\
\hline Meyeria? & harveyi & Woodward, 1900 & U. Cretaceous & ----- & $\begin{array}{l}\text { Hornby Island, BC } \\
\text { Canada }\end{array}$ \\
\hline \multicolumn{6}{|l|}{ Astacidea } \\
\hline Hoploparia & & $M^{\prime}$ Coy, 1849 & & & \\
\hline Hoploparia & bennetti & Woodward, 1900 & Late Cretaceous & & $\begin{array}{l}\text { British Columbia, } \\
\text { Canada }\end{array}$ \\
\hline Hoploparia & horrida & $\begin{array}{l}\text { Schweitzer, Feldmann, } \\
\text { Fam, Hessin, Hetrick, } \\
\text { Nyborg, \& Ross, } 2003\end{array}$ & e. Campanian & Pender Formation & $\begin{array}{l}\text { Vancouver Island, BC } \\
\text { Canada }\end{array}$ \\
\hline Hoploparia & riddlensis & Feldmann, 1974 & Hauterevian & $\begin{array}{l}\text { Days Creek } \\
\text { Formation }\end{array}$ & Oregon \\
\hline Hoploparia & shastensis & Rathbun, 1929 & L. Cretaceous & Chico Formation & California \\
\hline Hoploparia & tshudyi & $\begin{array}{l}\text { Schweitzer \& } \\
\text { Feldmann, } 2001\end{array}$ & 1. Albian & $\begin{array}{l}\text { Moonshine } \\
\text { Formation }\end{array}$ & $\begin{array}{l}\text { Wrangell Mts., Alaska } \\
\text { USA }\end{array}$ \\
\hline Palaeonephrops & & Mertin, 1941 & & & \\
\hline Palaeonephrops & ornatus & (Whiteaves, 1887) & Late Cretaceous & & $\begin{array}{l}\text { British Columbia, } \\
\text { Canada }\end{array}$ \\
\hline
\end{tabular}


map (Deméré, 1987).The locality exposes the Point Loma Formation in the Rosario Group, late Campanian in age. The matrix surrounding the specimens is a fossiliferous mudstone supporting sand size fragments of molluscs arrayed in what appear to be crude bedding surfaces. The lobsters are preserved within the matrix with no evidence of concretion formation.

Diagnosis. Hoploparia with well-developed cervical and postcervical grooves and faint branchiocardiac groove; with accessory intercervical and sellar grooves. Carapace ornamentation grades from granular to scabrous in cephalic region to nearly smooth in branchial region. Pleura and terga not separated by a crest.

Description. Moderate size for genus; dorsal margin straight with axial linea; posterior margin weakly sinuous; ventral margin smoothly convex with deepest point in posterior half. Total carapace length including rostrum, $56.0 \mathrm{~mm}$; length from base of orbit to posterior margin, $39.2 \mathrm{~mm}$; length from base of orbit to where postcervical groove crosses midline, $20.4 \mathrm{~mm}$; carapace height $25.7 \mathrm{~mm}$ measured at postcervical groove. Rostrum long, sulcate, curved downward proximally and upward distally. Rostral carina (R) strongly developed at least to mid-length where rostrum is broken. Rostral termination a sharp upward directed spine; lateral tooth (3) situated near terminus. Cephalic region finely granular anteriorly, becoming finely scabrous between cervical and postcervical grooves. Branchial region bearing a few granules. Orbital carina $(\mathrm{O})$ distinct; orbit deepest ventrally. Supraorbital carina $(\mathrm{P})$ smooth or with diminutive spines. Postorbital spine (8) short, prominent. Antennal carina (A) broad with sharp crest.

Cervical groove (e-e') deeply impressed, bounded posteriorly by row of coarse granules; extending from mid-height of carapace, curving ventrally into deep antennal groove (b) which bifurcates anteriorly into short, straight element and longer dorsally curved segment terminating at antennal carina (A). Inferior groove (i) deeply impressed, not extending to ventral margin. Postcervical groove (c) deeply impressed at midlength, shallow crossing midline, and obscure ventrally. Intercervical groove (c') subtle, most prominent near postcervical groove. Sellar groove (s) deep, concave forward. Branchiocardiac groove (a) diverges from postcervical groove becoming obscure posteriorly. Posteromarginal carina (PM) and groove (p.m.) strongly developed, terminating at posteroventral corner.

Pleon with six somites present; telson and uropods not preserved. Overall surface of pleon smooth. Pleonite 1 length $5.5 \mathrm{~mm}$, measured along midline of paratype. Pleonites 2 and 3 length 7.1 $\mathrm{mm}$; pleonite 4 length $8.6 \mathrm{~mm}$, pleonite 5 length $7.2 \mathrm{~mm}$, pleonite 6 length about $10.4 \mathrm{~mm}$. Pleuron 2 reniform with anterior lobe larger than posterior lobe. Pleura 3-5 cordate with short, sharp spine on posterior ventral corner.

Basal article of antenna stout, longer than high. Parts of basal articles of right and left chelipeds preserved. Right merus broadens distally, smooth. Carpus stout, slightly higher than long; two spines along midheight of outer surface. Propodus ovoid in cross-section, broken. Merus and carpus of left cheliped crushed, incomplete. Propodus broadens distally, compressed in cross-section, weakly sulcate along lower edge of outer surface.

Discussion. The species is represented by two specimens, the holotype, SDSNH 34151, consisting of an articulated cephalothorax and pleon as well as proximal elements of the chelipeds, and the paratype, SDSNH 34152, an isolated pleon comprising six pleonites but absent the telson and uropods. The pleon on both specimens is strongly flexed suggesting a condition of rigor, which in turn may suggest that the specimens are remains of corpses in which the muscles of the pleon are present. Strong flexure of the pleon results as the anterior oblique muscles contract upon death. These muscles form the major muscle mass in the pleon; the dorsal pleonal muscles, which are responsible for extending the pleon, are weaker (Feldmann and Schweitzer, 2010).

The cuticle on the holotype is strongly fractured in the branchial region and on the pleon, whereas that of the paratype is intact. In the posteroventral portion of the branchial region on the holotype, 


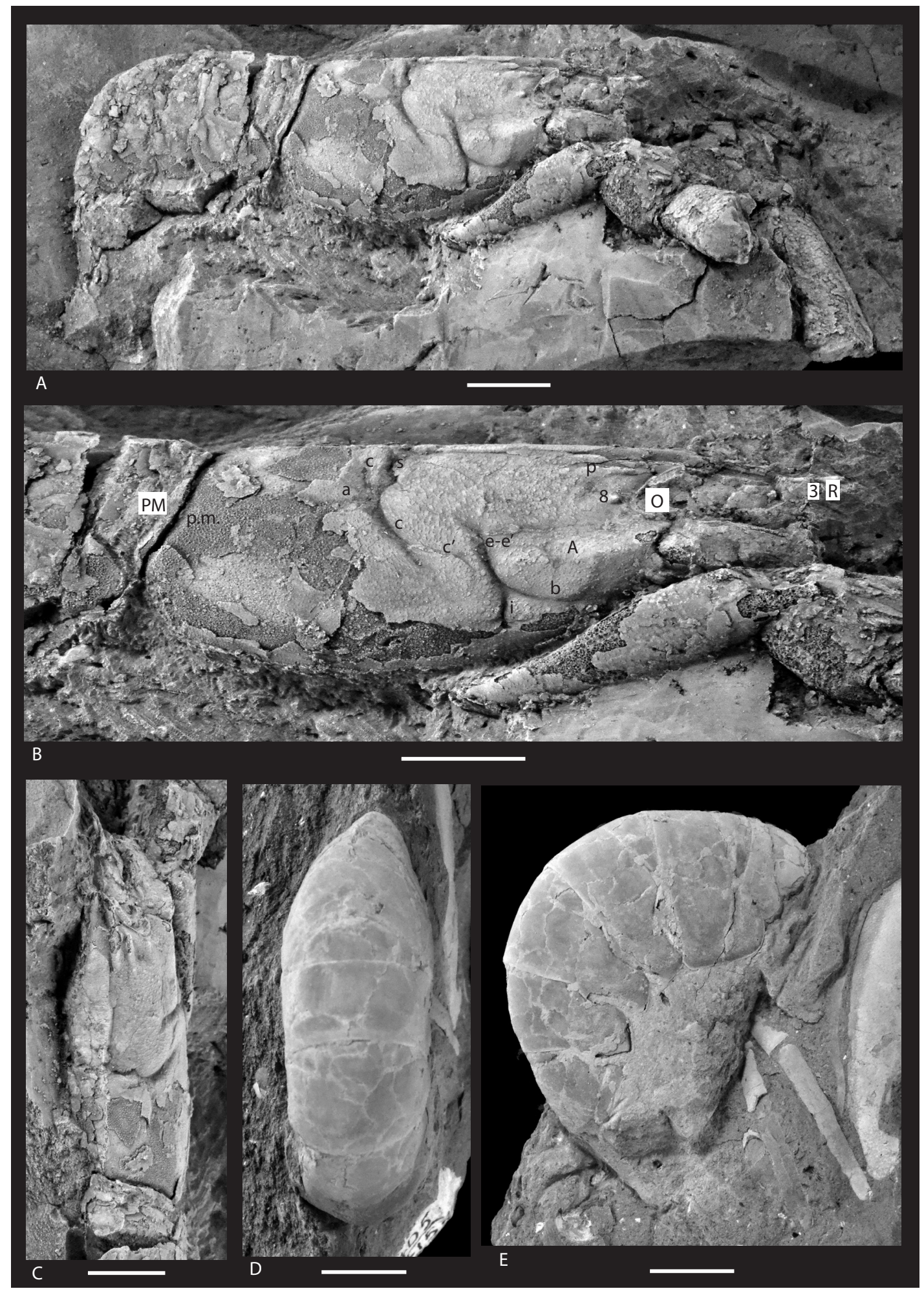

Figure 1 Hoploparia bretoni n. sp. A-C, holotype, SDSNH 34151, A, right lateral view of carapace, pleon, and right cheliped; B, closeup of carapace with morphology labeled; C, dorsal view of cephalothorax and rostrum. D-E, paratype SDSNH 34152, D, dorsal view of pleon, $\mathrm{E}$, right lateral view of pleon. Scale bars $=1 \mathrm{~cm}$. Abbreviations: $\mathrm{a}=$ branchiocardiac groove, $\mathrm{A}=$ antennal carina, $\mathrm{b}=\mathrm{antennal}$ groove, $\mathrm{c}=$ postcervical groove; c' = intercervical groove, e-e' = cervical groove, $\mathrm{i}=$ inferior groove, $\mathrm{o}=$ orbit, $\mathrm{P}=$ supraorbital carina, $\mathrm{PM}=$ posteromarginal carina, p.m. = postmarginal groove, $R=$ rostrum, $3=$ lateral rostral spine, $8=$ post-orbital spine. 
the exocuticle surface is generally dense whereas the surface of the endocuticle exhibits a fine reticulate pattern (Figure 2). The surface of the mold of the interior of the cuticle is granular.

Placement of this new species in Hoploparia is confirmed by its having a typical nephropid form and exhibiting a long rostrum with suprarostral spines, the subdorsal carina, well developed cervical and postcervical grooves, and a faint branchiocardiac groove (Feldmann et al., 2016). The new species is distinguished from the previously known species by possessing a pattern of carapace ornamentation of fine granules grading into a scabrous field in the cephalic region and a smooth branchial surface. A sellar groove is prominent and the intercervical groove, although present, is subtle. Although nearly all species of Hoploparia have a well-developed demarcation between the tergum and pleuron, none is present on the new species. The pleuron of the second pleonite is typically bounded by a crest; such feature is not present on the new species. Thus, the combination of features supports assignment to a new species. The genus is one of the most speciose of the lobster taxa, with 67 species (Schweitzer et al., 2010) ranging from Berriasian (Early Cretaceous) to Miocene.

\section{Discussion}

The extensive list of taxa collected from locality 3405 is dominated by molluscs, including in order of abundance, bivalves, gastropods, and cephalopods; an echinoid and four brachiopod valves represent the remaining invertebrates (Deméré,

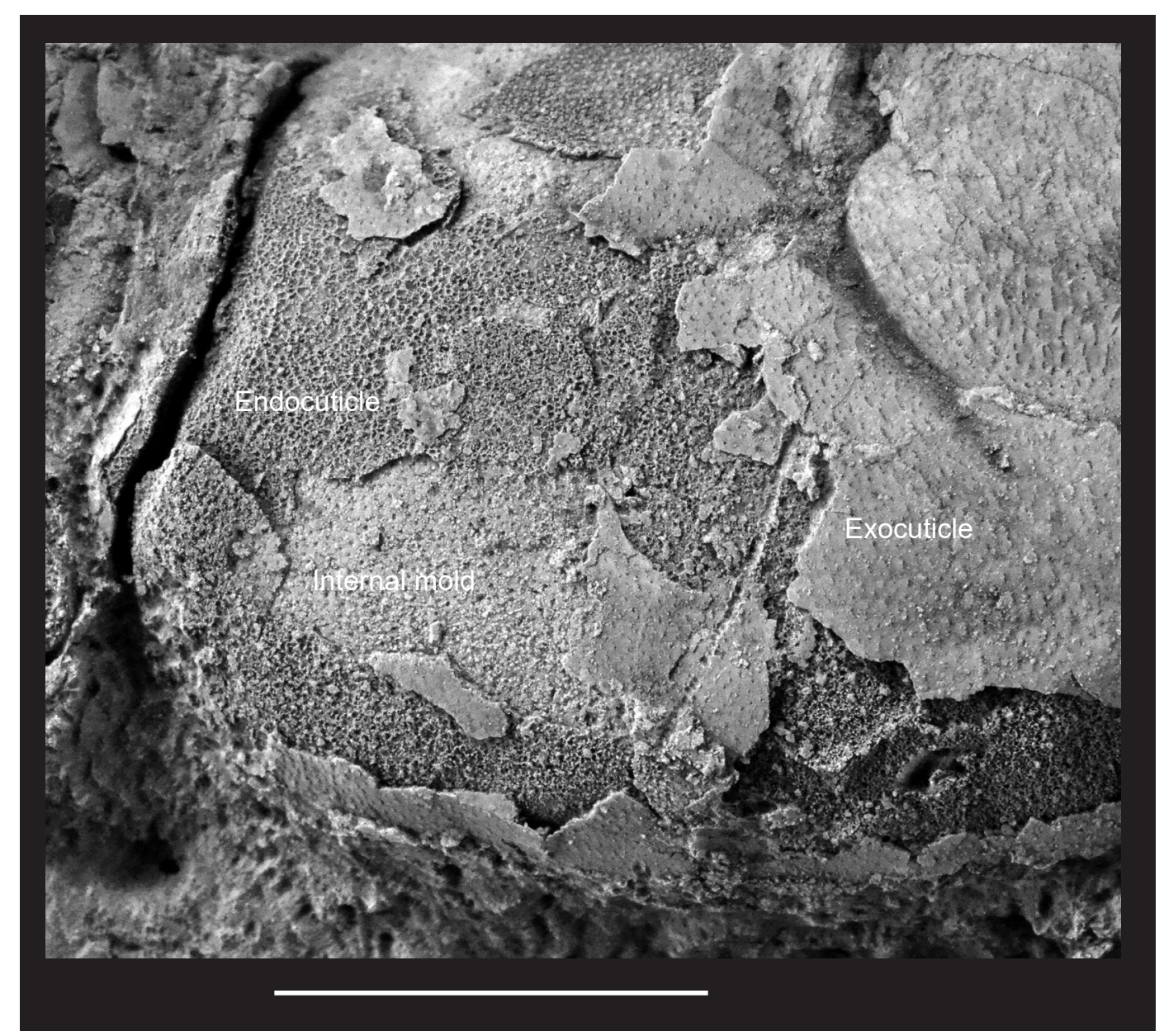

Figure 2 Cuticular layers of Hoploparia bretoni n. sp., holotype, SDSNH 34151, right posterolateral area. Scale bar $=1 \mathrm{~cm}$. 
1987). Two shark vertebrae and a single hadrosaur tooth represent the only vertebrate remains. The shark as well as the cephalopods and some of the gastropods comprise the predatory members of the assemblage other than the decapods. The brachyurans and Hoploparia bretoni n. sp. represent a trophic position of mobile predators/scavengers that are underrepresented in the Point Loma Formation. The generally well-preserved remains of the decapods suggests that other members of the group may be anticipated when additional exposures are available.

\section{Acknowledgements}

Specimens forming the basis for this study as well as the detailed locality register documenting the locality were provided by T. Deméré, Curator of Paleontology of the Department of Paleontology, San Diego Natural History Museum in San Diego, California, USA. The paper benefited from a review by G. Schweigert, SMNS, Germany.

\section{References}

Ahyong, S., 2009, The Polychelidan lobsters: phylogeny and systematics (Polychelida: Polychelidae), in Martin, J.W, Crandall, K. A., and Felder, D. L. (eds.), Decapod Crustacean Phylogenetics, Crustacean Issues 18, GRC Press, New York, pp. 369-396,. https://doi. org/10.1201/9781420092592-c19

Amati, L., Feldmann, R. M., Zonneveld, J.P., 2004, A new family of Triassic lobsters (Decapoda: Astacidea) from British Columbia and a cladistic analysis of the infraorders Astacidea and Palinura: Journal of Paleontology, 78 (1), 150-168. https://doi.org/10.1666/00223360(2004)078\%3C0150:anfotl\%3E2.0. со;2

Bell, T., 1858, A monograph of the fossil malacostracous Crustacea of Great Britain, Pt. I, Crustacea of the London Clay:
Monograph of the Palaeontographical Society, London, 10,1-44 p.

Beurlen, K., 1928, Die Decapoden des schwäbischen Jura mit Ausnahme der aus den oberjurassischen Plattenkalken stammenden: Palaeontographica, 70, 115-278.

Bishop, G.A., 1988, Two crabs, Xandaros sternbergi (Rathbun, 1926) n. gen., and Icriocarcinus xestos $n$. gen., n. sp., from the Late Cretaceous of San Diego County, California, USA, and Baja California Norte, Mexico: Transactions of the San Diego Society of Natural History, 21, 245-257. https://doi.org/10.5962/bhl. part. 24586

Dana, J. D., 1852, Parts I and II, Crustacea. U.S. Exploring Expedition During the Years 1838, 1839, 1840, 1841, 1842, Under the Command of Charles Wilkes, U.S.N., 13: Sherman, Philadelphia, 1618 p.

De Haan, W., 1833-1850, Crustacea, in von Siebold, P. F. (ed.), Fauna Japonica sive Descriptio Animalium, quae in Itinere per Japoniam, Jussu et Auspiciis Superiorum, qui summum in India Batava Imperium Tenent, Suscepto, Annis 1823-1830 Collegit, Notis, Observationibus et Adumbrationibus Illustravit. J. Müller et Co., Lugduni Batavorum (Leyden). https://doi. org/10.5962/bhl.title.124951

Deméré, T., 1987, Department of Paleontology Locality 3405 Card and Faunal List: San Diego Natural History Museum.

Feldmann, R.M., 1974, Hoploparia riddlensis, a new species of lobster (Decapoda: Nephropidae) from the Days Creek Formation(Hauterivian, Lower Cretaceous) of Oregon: Journal of Paleontology, 48 (3), 586-593.

Feldmann, R.M., Haggart, J.W., 2008, A new species of lobster (Astacidea, Erymidae) from the Smithers Formation (Middle Jurassic) of British Columbia, Canada: Canadian Journal of Earth Sciences, 44, 1791-1796. https://doi.org/10.1139/e07-058

Feldmann, R.M., Schweitzer, C.E., 2010, The oldest shrimp (Devonian: Famennian) and 
remarkable preservation of soft tissue: Journal of Crustacean Biology, 30 (4), 629635. https://doi.org/10.1651/09-3268.1

Feldmann, R.M., Schweitzer, C.E., 2017, Scyllarella (Decapoda: Achelata: Scyllaridae) from the Lookingglass Formation (Eocene): first occurrence on western coast of North America: Bulletin of the Mizunami Fossil Museum, 43, 11-15.

Feldmann, R.M., Schweitzer, C.E., Haggart, J.W., 2013, A new genus and species of lobster (Crustacea, Decapoda, Eryonidae) from the Early Jurassic (Hettangian) of British Columbia: Canadian Journal of Earth Science, 50, 135-141. https://doi. org/10.1139/cjes-2012-0120

Feldmann, R.M., Schweitzer, C.E., Haggart, J., 2020, A new erymoid lobster (Decapoda: Glypheidea: Erymidae) from the Upper Cretaceous of British Columbia, Canada, and a summary of Erymoidea from North America: Journal of Crustacean Biology, 40(3), 269-276. https://doi.org/10.1093/ jcbiol/ruaa005

Feldmann, R.M., Schweitzer, C.E., Karasawa, H., 2016, Part R, Revised, Volume 1, Chapter 8J: Systematic descriptions: Infraorder Astacidea: Treatise Online, 74, 1-28. https:// doi.org/10.17161/to.v0i0.5676

Fraaije, R.H.B., Jagt, J.W.M., van Bakel, B.W. M., Tshudy, D.M., 2018, New lobsters (Decapoda, Nephropoidea) from the Cretaceous-Paleogene section of the Middle Vistula valley, east-central Poland: Acta Geologica Polonica, 68 (4), 503-509. https:// doi.org/10.1515/agp-2018-0014

Holthuis, L.B., 1974, The lobsters of the superfamily Nephropidea of the Atlantic Ocean (Crustacea, Decapoda): Bulletin of Marine Science, 24, 723-884.

Latreille, P.A., 1802-1803, Histoire naturelle, générale et particulière, des Crustacés et des Insectes, 3, F. Dufart, Paris, 468 p. https:// doi.org/10.5962/bhl.title. 15764
M'Coy, F., 1849, On the classification of some British fossil Crustacea with notices of new forms in the University Collection at Cambridge, Annals and Magazine of Natural History series 2, 161-179.

Mertin, H., 1941, Decapode Krebse aus dem subhercynen und Braunschweiger Emscher und Untersenon sowie Bemerkungen über verwandte Formen in der Oberkreide: Nova Acta Leopoldina, 10 (68), 149-264.

Quenstedt, F.A., 1856-1857, Der Jura, Verlag der H. Lauppschen Buchhandlung, Tübingen, 1-842.

Rathbun, M.J., 1926, The fossil stalk-eyed Crustacea of the Pacific slope of North America: United States National Museum Bulletin, 138, 155 p. https://doi.org/10.5479/si.03629236.138.i

Rathbun, M.J., 1929, New species of fossil decapod crustaceans from California: Journal of the Washington Academy of Sciences, 19 (21), 469-472.

Rathbun, M.J., 1935, Fossil Crustacea of the Atlantic and Gulf Coastal Plain: Geological Society of America, 2, 160 p. https://doi. org/10.1130/spe2

Scholtz, G., Richter, S., 1995, Phylogenetic systematics of the reptantian Decapoda (Crustacea, Malacostraca): Zoological Journal of the Linnean Society, 113, 289-328. https:// doi.org/10.1111/j.1096-3642.1995.tb00936.x

Schweitzer, C.E., Feldmann, R.M., 2001, New Cretaceous and Tertiary decapod crustaceans from western North America: Bulletin of the Mizunami Fossil Museum, 28, 173210.

Schweitzer, G.E., Feldmann, R.M., Garassino, A., Karasawa, H., Schweigert, G., 2010, Systematic List of Fossil Decapod Crustacean Species: Crustaceana Monographs, 10, Brill, Leiden, 222 p. https://doi.org/10.1163/ ej.9789004178915.i-222

Schweitzer, C.E., Feldmann, R.M., Fam, J., Hessin, W.A., Hetrick, S.W., Nyborg, T.G., Ross, R. L. M., 2003, Cretaceous and Eocene decapod crustaceans from the Georgia Basin, British 
Columbia, Canada, National Research Council of Canada Memoir Series, 66 p.

Sowerby, J., 1826, Description of a new species of Astacus, found in a fossil state at Lyme Regis: Zoological Journal, 2, 493-494.

Tshudy, D., Hyžný, M., Dulai, A., Jagt, J. W.M., 2018, Appraisal of the fossil record of Homarus (nephropid lobster), with description of a new species from the upper Oligocene of Hungary and remarks on the status of Hoploparia: Journal of Paleontology, 92, 170182. https://doi.org/10.1017/jpa.2017.65

Van Straelen, V., 1925, Contribution à l'étude des Crustacés Décapodes de la période jurassique: Mémoires d'Académie Royale de Belgique, 2, $462 \mathrm{p}$.

Von Meyer, H., 1835, Briefliche Mitteilungen: Neues Jahrbuch für Mineralogie, Geologie, Geognosie, und Petrefaktenkunde, 329 p.

White, A., 1847, List of the Specimens of Crustacea in the Collection of the British Museum, British Museum, London, 143 p. https://doi.org/10.5962/bhl.title.1708

Whiteaves, J. F., 1885, Report on the Invertebrata of the Laramie and Cretaceous rocks in the vicinity of the Bow and Belly Rivers and adjacent localitites in the North-West
Territory: Geological and Natural History Survey of Canada Contribution to Canadian Palaeontology, 1 (1), 87-89. https://doi. org/10.4095/106560

Whiteaves, J.F., 1887, On some fossils from the Cretaceous and Laramie rocks of the Saskatchewan and its tributaries: Geology and Natural History Survey of Canada, Annual Report, 2, 152-166.

Whiteaves, J.F., 1895, On some fossils from the Nanaimo Group of Vancouver Cretaceous: Transactions of the Royal Society of Canada, 2, 119-133.

Whiteaves, J.F., 1903, On Some Additional Fossils from the Vancouver Cretaceous, with a Revised List of the Species Therefrom: Geological Survey of Canada, part 5, 309-416. https://doi.org/10.1017/ s0016756800123921

Winkler, T.C., 1881, Étude carcinologique sur les genres "Pemphix", "Glyphea" et "Araeosternus": Archive du Musée Teyler, (2) 1, 73-124.

Woodward, H., 1900, Further notes on podophthalmous Crustacea from the Upper Cretaceous formation of British Columbia: Geological Magazine, 7, 392-401. https:// doi.org/10.1017/s0016756800183311 